Were there any such laws of elevation and subsidence as Mrr. Howorth maintains, the respective regions of elevation? and of subsidence would have continued the same since the consolidation of the earth : but this is contradicted by the commonest facts of stratification, which show that elevation and subsidence have everywhere altemated with each other.

Old Forge, Dunmurry, co. Antrim JOSEPH JOHN MURPhy

The Use of Terms in Cryptogamic Botany

As no specialist in Algology has replied to the inquiry of your correspondent "D. R.," in NATURE for January 15, I may be permitted toquote for his information the following from the article "Nucleus, "in the "Treasury of Botany" from the pen of the author of the "Introduction to Cryptogamic Botany" :-.."In Alga the term is applied to the fructifying mass of the Rhodosperms, whether contained in a single cell or in a compound cyst or conceptacle, the word mucleoli being used when there is a group of nuclei." The instance alluded to by your correspondent is, unfortunately, not the only one in which the terminology of cryptogams is in a state of most perplexing confusion. ALFRED W. BENNETT

\section{A Lecture Experiment}

THE condensation of liquid in the form of vapour into minute globules, and the production of a shower of rain, may be very well illustrated for class purposes in the following manner :-

Place about an ounce of Canada balsam in a Florence flask, and let it boil. At the top of the flask clouds of globules of turpentine will be seen hovering about, altering in shape very much like sky-clouds, and the globules are large enough to be visible by the naked eye. If a cold glass rod be gradually intro. duced into the flask, these clouds may be made to descend in showers. By the adaptation of a lime-light the whole process could be shown on a screen.

LAWSON TAIT

\section{TODHUNTER ON EXPERIMENTAL ILLUSTRATIONS}

Segnius irritant animos demissa per atirem, guam quæ sunt oculis subjecta fidelibus, et qua ipse sibi tradit spectator.

T HE following is, as nearly as I can recollect, the substance of a few remarks which I felt myself compelled to make to my class in a recent lecture. I had exhibited and described Hope's apparatus for showing the maximum density point of water, and proceeded to say :--

Now that the freezing mixture has been applied, my assistant will from time to time record on the black-board the simultaneous indications of the two thermometers, and will recall our attention to the experiment as the critical period approaches. You must, hoviever, in this form of experiment take for granted his fidelity and accuracy in reading and recording. By meens of a somewhat cumbrous application of optical processes, it would be easy to project upon a screen images of the thermometers, in such a way that each of you might see for himself the course of the phenomenon. But the thermo-electric method, whose principle I have already explained to you, is at once far easier of application, and in its indications more directly expressive. This I will show on another occasion. For the present you must rely on the observations to be made for you by my assistant. Yet I have no doubt that all of you will allow that the exhibition of the experiment, even in this imperfect manner, wonderfully assists you in understanding its nature.

This leads me to mention that a very decided opinion against the use of experimental illustration has been recently pronounced by one of the most erudite and voluminous of British mathematicians; my own former tutor, Mr. Todhunter, whose name and many of whose works must be familiar to most of you. Such a man. speaks, deservedly with authority, on many points; and therefore his dicta upon a point with which he shows himself to be totally unacquainted are especially dangerous. And I feel that it is my duty to point out to you, and warn you against, errors or absurdities connected with physics, whenever they come from one whose statements are, on other grounds, worthy of attention. I shall not trouble you with the whole passage I refer to in Mr. Todhunter's "Conflict of Studies," but merely read to you a sentence or two of the most astounding part of it. I premise that though he is speaking of the teaching of physical science in schools, his observations apply (if they have any basis whatever) to science-teaching in general.

"It may be said that the fact makes a stronger impression on the boy through the medium of his sight, that he believes it the more confidently. I say that this ought not to be the case. If he does not believe the statements of his tutor-probably a clergyman of mature knowledge, recognised ability, and blameless character-his suspicion is irrational, and manifests a want of the power of appreciating evidence, a want fatal to his success in that branch of science which he is supposed to be cultivating."

Verbal comment on this would be altogether superfluous, and the only practical comment I am disposed now to make is to proceed at once to farther experimental illustrations of the subject before us.

\section{P. G. TAIT}

\section{POLARISATION OF IIGHT:}

V.

$7 \mathrm{HE}$ conversion of plane into circularly polarised light may also be effected by total reflexion. If planepolarised light traversing glass be incident upon the inner side of the limiting surface at any angle at which total reflexion takes place, it may be considered as resolved into two plane-polarised rays, the vibrations of one being parallel and those of the other perpendicular to the plane of reflexion; and there is reason to believe that in every such case a difference of phase is brought about which for a particular angle in each substance (in St. Gobain glass it is $54^{\circ} 30^{\prime}$ ) it has a maximum value of one-eighth of a wave-length. And if the criginal plane of vibration be inclined at an angle of $45^{\circ}$ to that of reflexion the amplitudes of the two vibrations, into which the reflected vibrations are supposed to be resolved, will be equal. A full cliscussion of the mechanical causes which may be considered to effect this difference of phase would carry us deeper into the more difficult parts of the Wave Theory than would be suitable in this place. But if we accept the fact that the above-mentioned effects result,

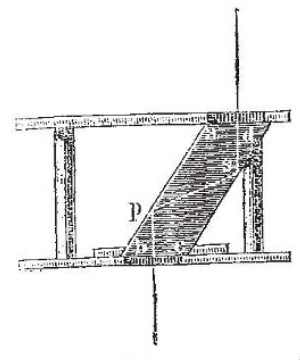

FIG. $r_{4}$. when polarised light (whose plane of vibration is inclined at $45^{\circ}$ to that of reflexion) is reflected at a proper angle; then the following construction will be readily understood. Take a rhomb of glass, $a, b, c, d$, Fig. I4, whose acute angles are $54^{\circ} 30^{\prime} ;$ a ray incident perpendicularly to either end will undergo two total internal reflexions at the sides, say at $p$ and $s$, and will emerge perpendicularly to the other end. These two reflexions will together produce a retardation, as described above, of one-fourth of a wave-length. And if the ray be originally polarised and its plane of vibration be inclined

* Continued from p. 285 . 